\title{
COMPONENT ANALYSIS AND MODELING OF AN IMPORTANT COSTS RATE OF PROJECT CONTRACT VALUE IN BUILDING CONSTRUCTION BUILDING
}

\author{
Agus Suroso $^{1}$, Erry Rimawan ${ }^{2}$, Windi Andhika ${ }^{3}$ \\ Civil Engineering, University of Mercu Buana \\ Industrial Engineering, University of Mercu Buana \\ Civil Engineering, University of Mercu Buana \\ agus.suroso@mercubuana.ac.id, erry.rimawan@mercubuana.ac.id, windiandhika@gmail.com
}

\begin{abstract}
Indirect costs are costs that are not directly related to project implementation but have a role in the construction work process. The indirect cost calculation process is not easy to do, the lack of information and guidance is still the cause. The difficulty of determining the percentage of indirect cost value for winning the tender, because each type of project has unique characteristics, this causes the amount of value in the indirect cost component is different for each - each project.

The most influential component of the total indirect cost value is the Equipment and Equipment component which has an average of $36.19 \%$, then the Management Cost and Field Coordination component with an average of $34.93 \%$ of the total indirect costs, and the Power Supply with an average of $14.41 \%$. The indirect cost of indirect cost to indirect contract cost ratio of $7 \%-14 \%$ in the contract value range Rp.100,000,000,000- Rp.200,000,000,000 indirect cost ratio $12 \%-14 \%$ for contract value Rp.200,000,000,000-Rp.300,000,000,000 and there was a decrease in the indirect cost ratio of $14 \%$ as the value of the project contract amounted to more than Rp.320,000,000,000.
\end{abstract}

Keywords: Indirect Cost, Tender, Building Construction Project

\section{INTRODUCTION}

The difficulty of determining the percentage of indirect cost value for winning tenders, because each type of project has its own unique characteristics, this causes the amount of value in the indirect cost component is different for each project. So when viewed as a whole, the percentage of indirect cost value of contract value has a varied value. How the indirect cost value is set for each of the components and what factors affect it can not be explained precisely because there is no standard for indirect cost calculations.

From the winning project data, the amount of the value for the indirect cost has a different range when viewed from the percentage of the indirect cost to the contract bid value. For example, for construction project of building A, the value of indirect cost is Rp.27.999.645.219 or 12.65\% from the contract value of the project, while the building construction project B value of indirect cost is Rp.29.029.537.000 or $16.25 \%$ from the value of the project contract, then for the construction project of building $\mathrm{C}$, the value of indirect cost of Rp.20.424.944.789 or $13.05 \%$ of the contract value of the project, then the building D building construction cost indirect cost of Rp.16.682.596.545 or 15, 12\% of the contract value of the project, and the E building cost project of indirect cost amounting to Rp.43,108,412,953 or $13.64 \%$ of the contract value of the project.

Hence the need for further research to analyze what components are contained in indirect costs so that it can vary value that affects the value of project offerings. Furthermore, to get accurate picture and pattern about this indirect cost estimation, so that in the next step can improve accuracy strategy to indirect cost calculation and optimization for tender winner.

\section{METHODOLOGY}

The research will be conducted with quantitative approach to determine the effect of indirect cost to the bid price. Furthermore, indirect cost component analysis with document review of contract value of budget plan cost. Quantitative approach is done to know the effect of indirect cost to the bid price at the time of the auction. The data analysis is done by descriptive statistic analysis which is meant to know the indirect cost component as well as the factors that influence it and know the amount by means of the percentage between the indirect cost and the contract value of the next project to do regression analysis done to get the model of indirect cost relationship to the value project contract. 
The population and instrument in this study which is the population is one of the main contractors with the classification of building business by taking fourteen building construction projects with the cost budget plan data that has won at auction and get the project contract.

The instrument to be used in this research is through analysis and document review of contract value of budget plan of building construction project. Data processing with descriptive statics and regression analysis will use software instruments using Microsoft Excel, where it will look for the value of indirect cost percentage with the contract value of the project.

\section{RESULTS AND DISCUSSION}

Descriptive Static Analysis of Indirect Cost Components From the discussion of indirect cost component analysis can be seen how the process of estimation and calculation of indirect costs made by the contractor for the building construction project does not make indirect cost estimates by means of percentage. A detailed and more careful calculation of the value for each component, and the process of correction and control over unnatural costs made it very important to be more likely to win the tender and to anticipate possible risks.

The most influential component of the total indirect cost value of $10 \mathrm{RAB}$ data analyzed is the Equipment and Equipment Equipment component has an average of $36.19 \%$, then the Management Cost and Field Coordination component with an average of $34.93 \%$ of the total indirect costs, and Power Supply with an average of $14.41 \%$.

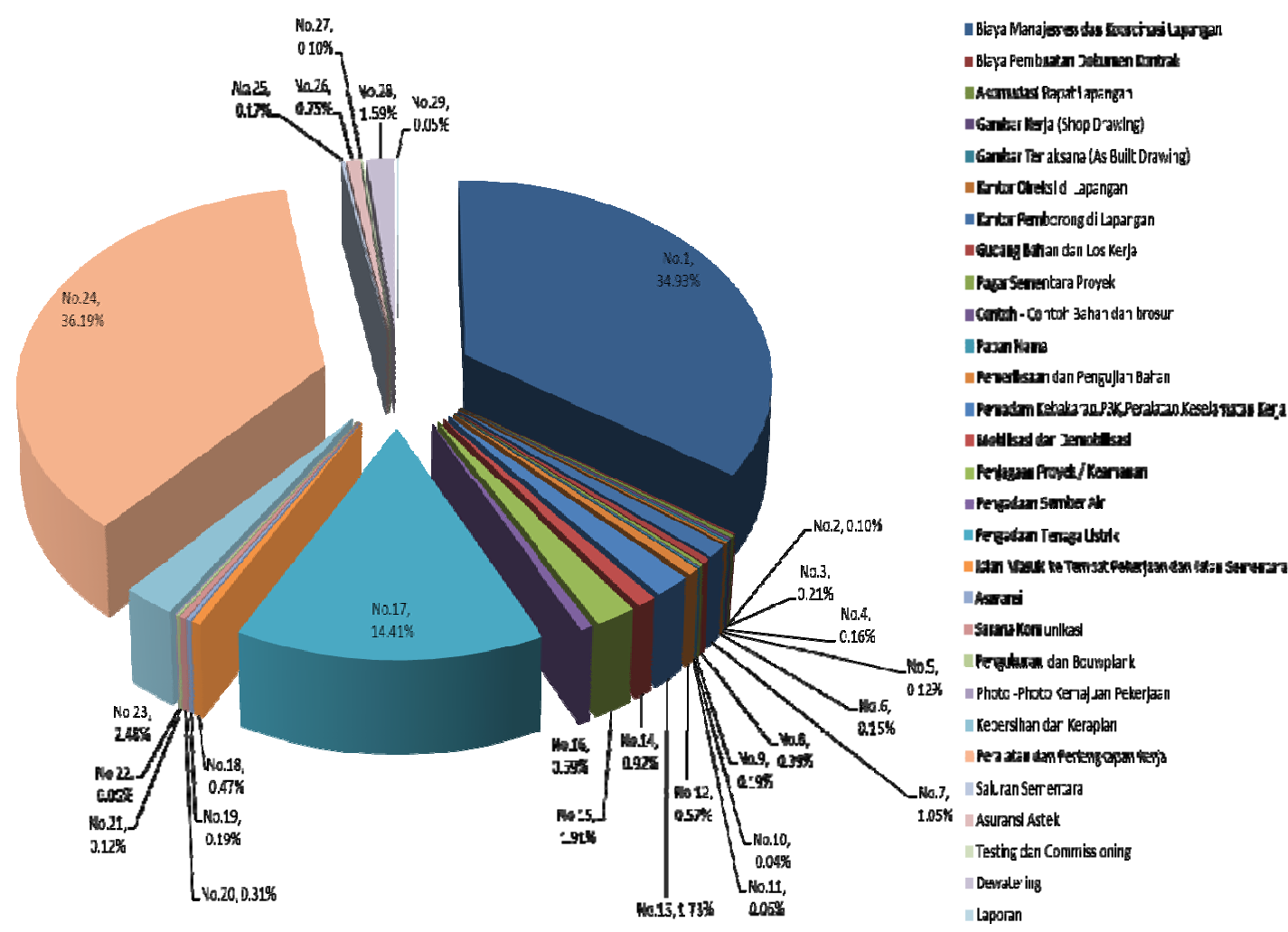

Figure 3.1 Average Indirect Cost Ratio (Source: Author Result, 2017)

\section{Regression Analysis}

Using regression analysis, a curve that describes the indirect cost to indirect cost ratio model with the contract value of the project. From contract value data and indirect cost ratio, then plotting data forming graph with $\mathrm{x}$ axis is the value of project contract and y axis is indirect cost ratio. 
Table 3.1 Indirect Cost Ratios Against Project Contract Value.

\begin{tabular}{|c|l|c|c|c|}
\hline No & \multicolumn{1}{|c|}{ Project Name } & $\begin{array}{c}\text { Indirect Cost Value } \\
\text { (Rp) }\end{array}$ & $\begin{array}{c}\text { Value of Project } \\
\text { Contract (Rp) }\end{array}$ & $\begin{array}{c}\text { Indirect Cost to } \\
\text { Contract Value (\%) }\end{array}$ \\
\hline 1 & Building Project A & $30,999,645,219$ & $221,351,000,000$ & $14.00 \%$ \\
\hline 2 & Building Project B & $28,956,087,000$ & $178,643,000,000$ & $16.21 \%$ \\
\hline 3 & Building Project C & $19,724,944,789$ & $156,475,000,000$ & $12.61 \%$ \\
\hline 4 & Building Project D & $16,682,596,545$ & $110,351,700,000$ & $15.12 \%$ \\
\hline 5 & Building Project E & $43,108,412,953$ & $316,035,000,000$ & $13.64 \%$ \\
\hline 6 & Building Project F & $48,366,133,000$ & $360,236,000,000$ & $13.43 \%$ \\
\hline 7 & Building Project G & $19,767,909,797$ & $169,960,600,000$ & $11.63 \%$ \\
\hline 8 & Building Project H & $16,956,000,000$ & $159,792,000,000$ & $10.61 \%$ \\
\hline 9 & Building Project I & $11,205,583,900$ & $121,160,294,000$ & $9.25 \%$ \\
\hline 10 & Building Project J & $6,846,292,450$ & $77,272,727,273$ & $8.86 \%$ \\
\hline 11 & Building Project K & $9,813,000,000$ & $97,405,000,000$ & $10.07 \%$ \\
\hline 12 & Building Project L & $10,064,443,000$ & $98,038,524,000$ & $10.27 \%$ \\
\hline 13 & Building Project M & $7,488,740,483$ & $83,228,000,000$ & $9.00 \%$ \\
\hline 14 & Building Project M & $4,600,000,000$ & $61,963,800,000$ & $7.42 \%$ \\
\hline
\end{tabular}

(Source: Author Result, 2017)

From the above data can be the mean or average value of the indirect cost ratio with the value of 0.1157 with the standard error of 0.00704 . The median of indirect cost ratio has a value of 0.1112 with a standard deviation of 0.02635 .

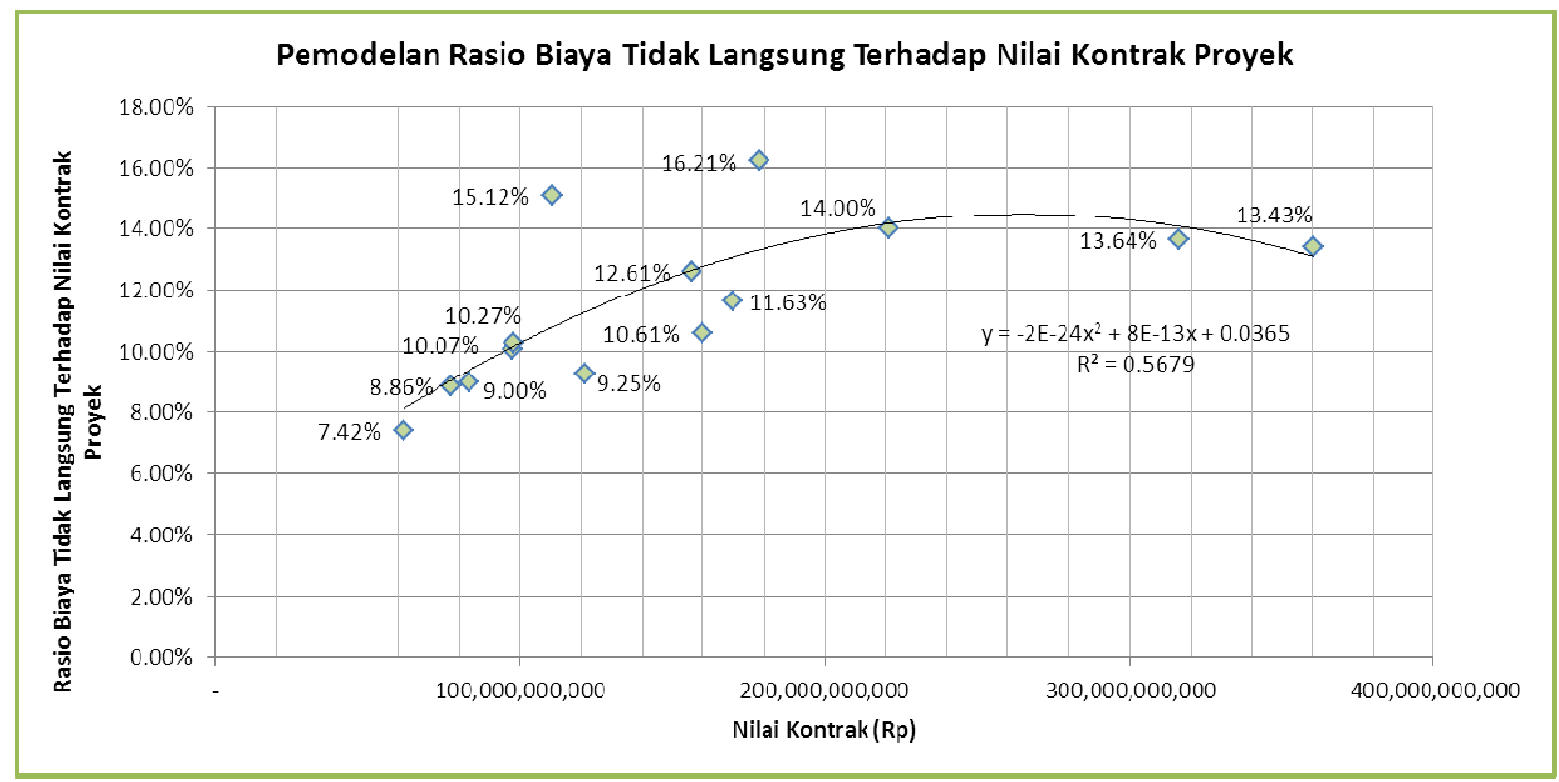

Figure 4.32 Relationship Model of Indirect Cost Ratio Against Contract Value (Source: Author Result, 2017)

From the graph above, the value of $\mathrm{R}$ square with a value that is not too high is $0.5679(<0.6000)$. $\mathrm{R}$ square value is the coefficient of multiple determination. The function of $\mathrm{R}$ square is to measure the goodness of fit of the regression equation, and give the percentage value of the total variation in the dependent variable described by the independent variable. $\mathrm{R}$ square value has range between $0-1$, and model match is said better if $\mathrm{R}$ square value close to 1 . 
Table 3.2 Elimination of Indirect Cost Ratio Data

\begin{tabular}{|c|c|c|c|}
\hline No & Project Name & $\begin{array}{c}\text { Indirect Cost to } \\
\text { Contract Value (\%) } \\
\end{array}$ & Deviation \\
\hline 1 & Building Project A & 0.14 & 0.02 \\
\hline 2 & Building Project B & 0.16 & 0.05 \\
\hline 3 & Building Project $\mathrm{C}$ & 0.13 & 0.01 \\
\hline 4 & Building Project D & 0.15 & 0.04 \\
\hline 5 & Building Project E & 0.14 & 0.02 \\
\hline 6 & Building Project $\mathrm{F}$ & 0.13 & 0.02 \\
\hline 7 & Building Project $\mathrm{G}$ & 0.12 & 0 \\
\hline 8 & Building Project $\mathrm{H}$ & 0.11 & -0.01 \\
\hline 9 & Building Project I & 0.09 & -0.02 \\
\hline 10 & Building Project J & 0.09 & -0.03 \\
\hline 11 & Building Project $\mathrm{K}$ & 0.1 & -0.02 \\
\hline 12 & Building Project L & 0.1 & -0.01 \\
\hline 13 & Building Project $\mathrm{M}$ & 0.09 & -0.03 \\
\hline \multirow[t]{3}{*}{14} & Building Project $\mathrm{N}$ & 0.07 & -0.04 \\
\hline & $\Sigma=$ & 1.62 & \\
\hline & Mean $(\mathrm{x}$ bar $)=$ & 0.12 & \\
\hline
\end{tabular}

(Source: Author Result, 2017)

To increase the value of $\mathrm{R}$ square will be eliminated data from building project $\mathrm{B}$ and building project $\mathrm{D}$, based on table 4:32 this is done because the deviation from the indirect cost ratio for both projects is too far so the regression analysis becomes less valid.

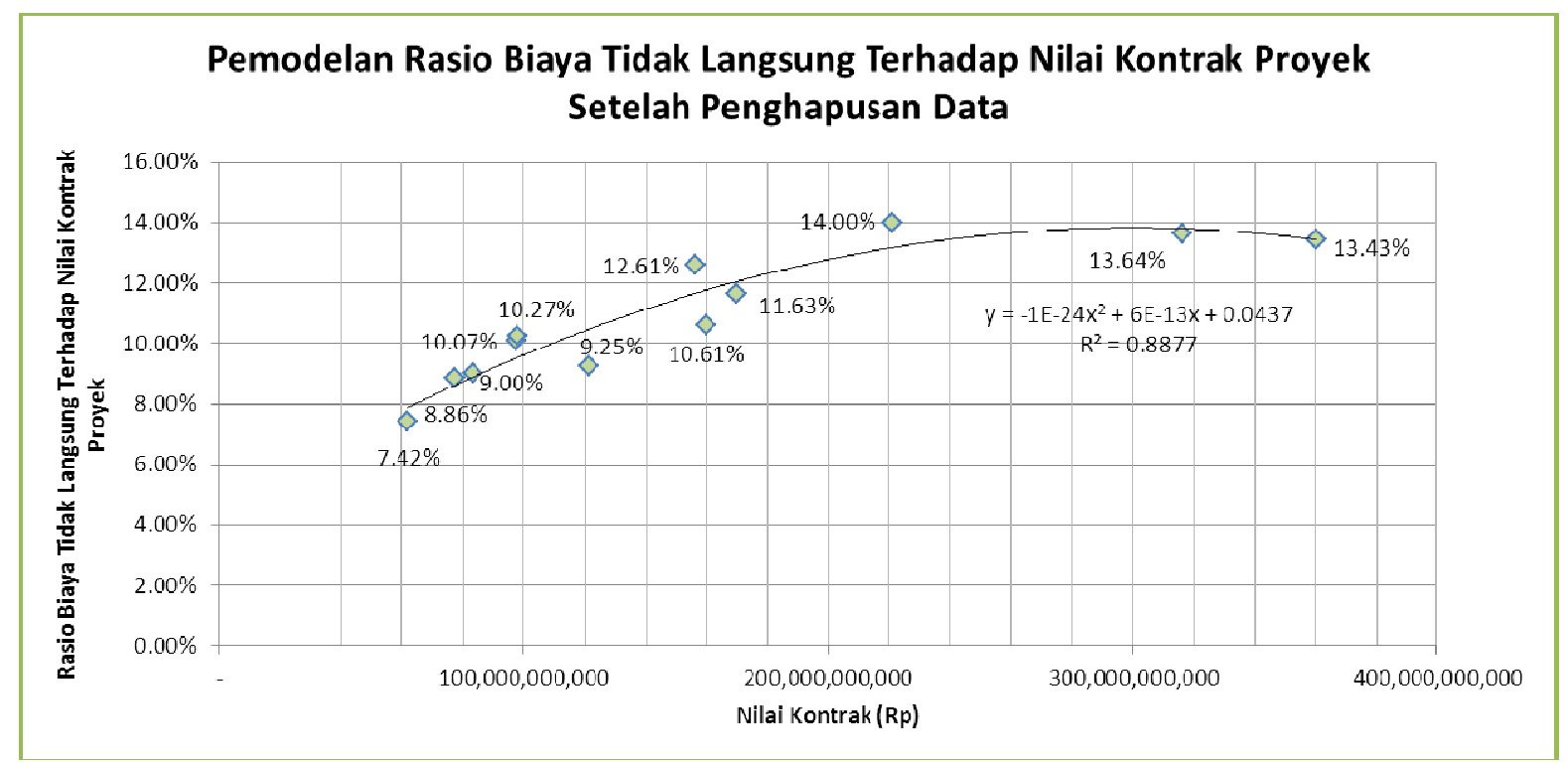

Figure 4.33 Relationship Model of Percentage of Indirect Costs to Contract Value After Data Elimination (Source: Author Result, 2017)

Regression analysis results obtained equation $\mathrm{y}=-1 \mathrm{E}-24 \mathrm{x} 2+6 \mathrm{E}-13 \mathrm{x}+0.0437$ with $\mathrm{R}^{2}=0.8877, \mathrm{x}$ is the value of project contract and $\mathrm{y}$ is indirect cost ratio variable to contract value. Can be seen from the data above, after the elimination of graph data regression analysis generated to make the value of $\mathrm{R}$ square becomes higher than the previous regression analysis is increased to 0.8877 this value is quite strong $(>0.6000)$ and has a positive value.

With the results of data from 14 projects with each indirect cost value and ratio to the contract value, it can be seen how the estimation pattern made by the contractor to the building project, where from the form of modeling the relationship of the percentage of indirect cost to the value of the contract that has been done has a significant indirect cost increase of $7 \%-14 \%$ in the contract value range of $\mathrm{Rp} \cdot 100,000,000,000$ Rp.200,000,000,000 and moves to the range of contract value Rp.200,000,000,000-Rp.300,000,000,000 indirect 
cost of indirect cost ratio with cost ratio not directly in the range of $12 \%-14 \%$, and there was a decrease in the indirect cost ratio as the value of the project contracts in the range of more than Rp.320,000,000,000.

The tendency to increase the indirect cost ratio can occur due to the higher difficulty level of the project, requiring increased resources not only quantity but also the quality where experts are needed with experienced in handling the project, this certainly affects the cost on the components of Management and Coordination Field. Then the increase also occurred in the cost of Equipment and Working Equipment related to working methods and the increasing need of Power Supply to work on projects with high difficulty level and indirect cost reduction indirectly occurred along with the increase of work volume and contract value of the project.

\section{CONCLUDE}

Factors that influence in determining indirect cost value are the type \& characteristics of the project, the method of job implementation, the estimator's ability to perform indirect cost calculation, management \& project organization overhead, preparation \& temporary building facilities, risk factors \& project quality, external parties related to the environment, community, and bureaucracy.

From the results of the analysis, the components included in the indirect costs are:

- Field Management and Coordination Costs,

- Cost of Contract Document Making,

- Accumulation of Field Meetings,

- Work Drawing,

- Picture Implemented (As Built Drawing),

- Office of Directors in the Field,

- Office of Contractor in the Field,

- Material and Loss Warehouse,

- Project Interim Fence,

- Examples Materials and brochures,

- Project Name Board,

- Materials Inspection and Testing,

- Fire Extinguisher, First Aid, Safety Equipment,

- Mobilization and Demobilization,

- Project / Security Maintenance,

- Procurement of Water Resources,

- Procurement of Electricity,

- Entrance Road to Work Place and Temporary Road,

- Insurance,

- Means of Communication,

- Measurements and Bouwplank,

- Job Progress Photos,

- Cleanliness and Tidiness,

- Equipment and Work equipment,

- Temporary Channels,

- Astek Insurance,

- Testing and Commissioning, Dewatering,

- Dewatering,

- Reports.

The most influential component of the total indirect cost value is the equipment and work equipment component has an average of $36.19 \%$, then the Management Cost and Field Coordination component with an average of $34.93 \%$ of the total indirect costs, and the procurement component of Power an average of $14.41 \%$.

The indirect cost of indirect cost to indirect cost contract $7 \%-14 \%$ in the contract value range Rp.100,000,000,000-Rp.200,000,000,000., Indirect cost ratio 12\% - $14 \%$ for contract value Rp.200,000,000,000Rp.300,000,000,000 , and there was a decrease in the indirect cost ratio of $14 \%$ as the value of the project contract on the contract value was more than Rp.320,000,000,000.

The result of regression analysis shows that $\mathrm{y}=-1 \mathrm{E}-24 \mathrm{x} 2+6 \mathrm{E}-13 \mathrm{x}+0.0437$ with $\mathrm{R}^{2}=0.8877, \mathrm{x}$ is the value of project contract and $\mathrm{y}$ is indirect cost to contract value with $\mathrm{R}$ square value is 0.8877 (88.77\%). The equation can be used as a control tool to determine the range of indirect cost values to the contract value of the project at the time of the tender offer for correction and control process of unreasonable cost as well as to maintain the chance to win the tender and can anticipate the possible risks of construction proces 


\section{References}

[1] Magaline, H. P., \& Haryono, A. J. (2010). Survei Mengenai Biaya Overhead Serta Faktor-Faktor Yang Mempengaruhinya, 1-8.

[2] Nugroho, P. S. (2015). Estimasi biaya tidak langsung pada kontraktor kecil di semarang. Prosiding Konferensi Nasional Teknik Sipil 9 (KoNTekS 9), 9, 7-8.

[3] Nurdiana, A. (2015). Analisis Biaya Tidak Langsung Pada Proyek Pembangunan Best Western Star Hotel \& Star Apartement Semarang. Teknik, 36 (2), 105-109.

[4] Project Management Institute. (2013). A Guide to the Project Management Body of Knowledge. Newtown Square, Pennsylvania, USA: Project Management Institute.

[5] Shelton, F., \& Brugh, M. (2002). Indirect Costs of Contracts. Journal Of Construction Accounting And Taxation, 3(August), 4-9.

[6] Soemardi, B. W. (2010). Studi Pratek Estimasi Biaya Tidak Langsung Pada Proyek Konstruksi. Konferensi Nasional Teknik Sipil 4 (KoNTekS 4) Sanur-Bali, 2-3 Juni 2010, 4, 2-3.

[7] Yusuf, D. (2010). Studi Estimasi Biaya Tidak Langsung Pada Proyek Konstruksi Pada Perusahaan Kontraktor Kualifikasi Besar di Daerah Bandung dan Jakarta. Thesis. Institut Teknologi Bandung. 